\title{
Peran Keluarga terhadap Manajemen Relapse (Kekambuhan) pada Orang Dengan Skizofrenia (ODS)
}

\author{
Ni Nengah Henny Meiantari dan Yohanes Kartika Herdiyanto \\ Program Studi Psikologi, Fakultas Kedokteran, Universitas Udayana \\ hennymeiantari@gmail.com
}

\begin{abstract}
Abstrak
Skizofrenia merupakan gangguan psikotik yang ditandai dengan gangguan utama dalam pikiran, emosi dan perilaku. Penanganan yang umum dilakukan oleh anggota keluarga yaitu mengajak orang dengan skizofrenia (ODS) untuk melakukan pengobatan ke dokter spesialis jiwa (psikiater) maupun berobat ke rumah sakit jiwa. Kurangnya pengetahuan keluarga dan masyarakat akan deteksi dini dan penanganan pasca pengobatan di rumah sakit jiwa menyebabkan ODS tidak memperoleh penanganan dengan baik. Penanganan yang kurang baik dapat menimbulkan gejala-gejala kekambuhan atau yang sering disebut relapse. Relapse atau kambuh dapat diartikan sebagai munculnya gejala yang sama seperti sebelumnya dan mengakibatkan ODS harus dirawat kembali. Relapse dipengaruhi oleh tiga faktor, yaitu obat, keluarga dan sosial. Berdasarkan hal tersebut, penelitian ini bertujuan untuk mengetahui bagaimana peran keluarga terhadap manajemen relapse (kekambuhan) pada orang dengan skizofrenia (ODS).

Penelitian ini menggunakan metode kualitatif dan desain penelitian fenomenologi. Pengambilan data dilakukan dengan menggunakan teknik wawancara dan observasi pada 10 orang responden dan wawancara kelompok pada 2 kelompok yang terdiri dari keluarga ODS. Analisis data dilakukan dengan reduksi data, data display dan conclusion drawing atau verification.

Hasil penelitian ini menunjukkan bahwa pencegahan yang dilakukan keluarga untuk meminimalisir munculnya relapse yaitu melakukan perlindungan dari stresor, memastikan ODS minum obat secara teratur, rutin melakukan kontrol ke dokter maupun rumah sakit dan mengajak ODS untuk beraktivitas. Penanganan yang dilakukan keluarga apabila gejala relapse muncul yaitu membawa ODS ke rumah sakit, memberikan obat, dan memberikan perhatian keluarga.
\end{abstract}

Kata kunci: peran keluarga, skizofrenia, relapse, ODS

\begin{abstract}
Schizophrenia is a psychotic disorder which characterized by major disorders in mind, emotion and behavior. The generally handling which done by the family members is invite the people with schizophrenia (ODS) to conduct treatment to a psychiatrist and also do some treatments in mental hospital. Lack of family and society knowledge of early detection and post-treatment handling in mental hospitals causing the $O D S$ not to get handled properly. Poor handling can cause symptoms of recurrence or often called relapse. Relapse or recurrence can be interpreted as the appearance of the same symptoms as before and causing the $O D S$ to be re-treated. Relapse is influenced by three factors, that are drug, family and social. Based on this, this research aims to find out how the family role in relapse management (recurrence) in people with schizophrenia $(O D S)$.

This research used qualitative method and phenomenology research design. The data were collected using interview and observation technique on 10 respondents and group interview in 2 groups consisting of $O D S$ 's family. The data analysis is done by data reduction, data display and conclusion drawing or verification.

The results of this research indicate that prevention of the family to minimize the emergence of relapse is to protect from the stressor, ensuring the $O D S$ regularly taking antipsychotic drugs, routine control to the doctor or hospital, and invite $O D S$ to move. Handling of the family when symptoms of relapse appear is bringing the $O D S$ to the hospital, giving antipsychotic drugs, and give the family attention.
\end{abstract}

Keywords: family role, schizophrenia, relapse, ODS 


\section{LATAR BELAKANG}

Kesehatan menurut Undang-Undang No. 23 Tahun 1992 yaitu keadaan sejahtera dari badan, jiwa dan sosial yang memungkinkan setiap orang hidup produktif secara sosial dan ekonomis. Kesehatan memiliki dua aspek, antara lain kesehatan fisik dan kesehatan mental (Indonesia, Undangundang no. 23 tahun 1992 tentang kesehatan, 1992). Kemampuan dalam menyeimbangkan aspek fisik dan mental tentu akan menghasilkan kesehatan yang baik, namun apabila terjadi ketidakseimbangan pada salah satu aspek maka akan menimbulkan gangguan, seperti gangguan pada mental. Gangguan mental yang timbul dapat berupa gangguan mental organik, gangguan mental dan perilaku akibat penggunaan psikoaktif, skizofrenia, gangguan skizotipal dan gangguan waham, gangguan suasana perasaan, gangguan neurotik dan retardasi mental (Maslim, 2013).

Skizofrenia adalah gangguan psikotik yang ditandai dengan gangguan utama dalam pikiran, emosi, dan perilaku (Davison, Neale, \& Kring, 2014). Prevalensi gangguan jiwa berat seperti skizofrenia di Indonesia adalah 1,7 kejadian per 1000 penduduk yang merupakan hasil Riset Kesehatan Dasar (Riskesdas) tahun 2013. Bali menjadi peringkat ketiga wilayah dengan gangguan kejiwaan berat di Indonesia dengan prevalensi mencapai 2,3 kejadian per 1000 penduduk (Idaiani, Yunita, Prihatini, \& Indrawati, 2013).

Gangguan jiwa berat menimbulkan beban berat bagi pemerintah, keluarga, dan masyarakat dikarenakan produktivitas pasien menurun dan akhirnya menimbulkan beban biaya yang besar bagi ODS (Orang dengan Skizofrenia) dan keluarga. Biaya pelayanan kesehatan yang besar menyebabkan masih banyak terdapat pemasungan dan perlakuan yang kurang tepat pada ODS di Indonesia (Idaiani, Yunita, Prihatini, \& Indrawati, 2013). Terdapat beberapa faktor yang memengaruhi pemasungan pada ODS, antara lain ketidaktahuan pihak keluarga, rasa malu pihak keluarga, penyakit ODS tidak kunjung sembuh, tidak adanya biaya pengobatan dan tujuan pemasungan adalah untuk mengamankan ODS agar tidak terjadi tindakan kekerasan (Mundakir, 2015).

Kurangnya pengetahuan keluarga dan masyarakat akan deteksi dini dan penanganan pasca pengobatan di rumah sakit jiwa menyebabkan ODS tidak memperoleh penanganan dengan baik (Lestari \& Wardhani, 2014). Faktor yang memengaruhi kestabilan ODS pasca pengobatan yaitu di samping dukungan keluarga adalah keteraturan dalam konsumsi obat. ODS memang sangat bergantung dengan obat, sehingga diperlukan peran keluarga dalam mengawasi konsumsi obat yang dijalani ODS. Hal ini ditunjang dengan hasil penelitian yang dilakukan oleh Amelia dan Anwar (2013) yang menyebutkan bahwa salah satu penyebab relapse (kambuh) pada ODS yaitu tidak patuhnya ODS dalam melakukan pengobatan dan konsumsi obat yang tidak teratur akibat dari faktor ekonomi keluarga (Amelia \& Anwar, 2013).

Penanganan pasca pengobatan penting dilakukan agar ODS tidak mengalami relapse serta ODS juga memiliki keharusan untuk beradaptasi di lingkungan barunya (Putri \& Ambarini, 2012). Penanganan yang dapat dilakukan keluarga adalah mengontrol konsumsi obat pada ODS. Pada kondisi ini, dukungan keluarga terhadap konsumsi obat yang biasa terlihat adalah keluarga menyiapkan obat setiap hari, memberi pengertian dan nasehat pada ODS agar mau minum obat, serta memiliki perasaan kasihan terhadap ODS (Minarni \& Sudagijono, 2015). Walaupun ODS rutin mengonsumsi obat, tetapi keadaan relapse tetap tidak dapat diprediksi. Relapse atau kambuh dapat diartikan sebagai munculnya gejala yang sama seperti sebelumnya dan mengakibatkan ODS harus dirawat kembali (Pencegahan kekambuhan pada orang dengan gangguan kejiwaan, 2015).

Terdapat beberapa penyebab relapse antara lain faktor ekonomi, ketidakpatuhan ODS dalam menjalani pengobatan, mendapatkan perlakuan kasar dan pertengkaran yang terusmenerus dengan saudara kandung, konflik yang berkepanjangan dengan pasangan (suami atau istri), dan emosi marah yang diekspresikan secara berlebihan oleh keluarga (Amelia \& Anwar, 2013). Pasca pengobatan, keluarga merupakan faktor utama yang memengaruhi keadaan ODS selanjutnya. Penelitian yang dilakukan oleh Taufik (2014) menyebutkan bahwa terdapat hubungan negatif antara dukungan keluarga dengan tingkat kekambuhan pasien skizofrenia di Poliklinik Rumah Sakit Grhasia Yogyakarta yang menunjukkan bahwa semakin baik dukungan keluarga, maka semakin menurun tingkat kekambuhan pasien skizofrenia, begitu pula sebaliknya (Taufik, 2014).

Dukungan sosial yang buruk memiliki kontribusi terhadap kekambuhan pada skizofrenia. Tanpa adanya dukungan keluarga atau sosial, ODS cenderung lalai dalam melakukan pengobatan karena tidak diawasi. Faktor lain yang memengaruhi proses pengobatan yaitu tidak adanya motivasi serta adanya masalah keuangan yang dialami ODS. Kurangnya dukungan sosial dapat pula menyebabkan tandatanda awal relapse tidak disadari dan ditangani dengan baik sehingga akan muncul relapse (Rao, 2013).

Relapse pada skizofrenia yaitu munculnya gejala yang sama seperti sebelumnya setelah masa remisi. Keadaan ini dapat mengakibatkan ODS dirawat kembali di rumah sakit. Gejala atau tanda relapse yang paling jelas adalah peningkatan atau kemunculan simtom positif (Burns et al. dalam Taylor, et al., 2005). Relapse juga dikaitkan dengan prognosis yang buruk dan kemampuan kognitif yang menurun, lebih banyak berada pada keadaan yang tidak sehat, risiko cedera, stigma yang meningkat terutama pasca rawat inap, penurunan kualitas hidup, kehilangan harga diri, dan gangguan sosial (Taylor, et al., 2005).

Dukungan keluarga dapat dilihat dari bagaimana cara keluarga melakukan manajemen skizofrenia. Manajemen skizofrenia jangka panjang memiliki tujuan yaitu untuk meningkatkan kualitas hidup ODS, memperoleh kembali tingkat kemandirian, mendorong ODS untuk membangun kepercayaan dimasyarakat, dan meminimalisir kemunculan relapse. Manajemen skizofrenia jangka panjang dapat menggunakan 3 strategi utama, antara lain: intervensi farmakologi, intervensi psikososial, dan inisiatif membangun aliansi dengan ODS dan perawat. Intervensi psikososial salah satunya dapat dilakukan secara efektif menggunakan terapi berbasis keluarga dengan salah satu tujuannya yaitu membantu 
ODS untuk membangun kepercayaan dimasyarakat dan untuk membangun kembali serta mempertahankan tingkat kemandirian ODS (Taylor, et al., 2005).

Salah satu strategi yang dapat digunakan untuk meminimalisir kemunculan relapse yaitu menggunakan terapi berbasis keluarga. Hal ini menunjukkan bahwa keluarga merupakan salah satu faktor yang mampu melakukan suatu manajemen untuk mengontrol kemunculan relapse. Salah satu hal yang dapat dilakukan keluarga adalah dengan melakukan manajemen relapse. Manajemen relapse merupakan salah satu cara untuk melihat bagaimana keluarga melakukan persiapan dalam menghadapi kemunculan relapse pada ODS. Kesiapan dalam menghadapi relapse dapat membantu keluarga untuk memastikan gejala-gejala yang muncul dapat diketahui lebih awal sehingga ODS dapat mendapatkan penanganan yang tepat. Memperbaiki sikap anggota keluarga dapat secara substansial mengurangi kemungkinan relapse pada ODS dan mendorong terbentuknya kepercayaan pada lingkungan sosial (Taylor, et al., 2005).

Berdasarkan hal tersebut, penelitian ini berfokus pada bagaimana peran keluarga dalam melakukan manajemen relapse (kekambuhan) pada ODS. Manajemen relapse yang dimaksud pada penelitian ini lebih menekankan pada usaha pencegahan dan penanganan yang dilakukan keluarga ketika ODS mengalami relapse.

\section{METODE PENELITIAN}

\section{Tipe Penelitian}

Penelitian ini dilakukan dengan menggunakan metode penelitian kualitatif. Moleong (2014) menjelaskan pengertian dari penelitian kualitatif merupakan penelitian yang dimaksudkan untuk memahami fenomena apa yang dialami oleh subjek penelitian secara holistik. Pada penelitian ini, peneliti ingin memperoleh informasi terkait apa saja yang dilakukan oleh keluarga dalam memanajemen relapse pada ODS. Data yang ingin diperoleh merupakan data yang mendalam dan komprehensif dalam menjelaskan langkahlangkah yang dilakukan keluarga dalam melakukan manjemen relapse. Pendekatan yang digunakan dalam penelitian ini yaitu pendekatan fenomenologi. Menurut Creswell (dalam Sugiyono, 2014), pendekatan fenomenologi adalah salah satu jenis penelitian kualitatif, pengumpulan data dilakukan dengan cara observasi partisipan untuk mengetahui fenomena esensial partisipan dalam pengalaman hidupnya.

\section{Karakteristik Responden}

Responden yang dilibatkan dalam penelitian ini dipilih melalui teknik purposive sampling, sehingga diperoleh 10 responden individu dan 2 kelompok responden yang terdiri dari keluarga ODS. Pertimbangan atau karakteristik subjek yang digunakan dalam penelitian ini ditetapkan berdasarkan kriteria inklusi dan eksklusi. Adapun kriteria inklusi dalam penelitian ini adalah: (1) Keluarga yang merawat anggota keluarga (care giver) yang terdiagnosa skizofrenia, (2) Keluarga pernah mengajak ODS melakukan pengobatan secara medis, baik ke dokter maupun rumah sakit.
Adapun kriteria eksklusi pada penelitian ini yaitu: (1) Bukan merupakan anggota keluarga dari seorang ODS, (2) Bukan merupakan care giver dari ODS, (3) Keluarga tidak pernah mengajak ODS melakukan pengobatan medis, (4) Responden tidak mengikuti wawancara dan observasi hingga selesai, (5) Tidak bersedia menjadi responden penelitian.

\section{Lokasi Pengumpulan Data}

Lokasi pengumpulan data dalam penelitian, khususnya yang melibatkan 10 responden individu dan 2 kelompok responden dilakukan di Bali. Responden penelitian juga merupakan keluarga ODS yang menjalani pengobatan atau perawatan di rumah sakit atau merupakan keluarga ODS yang tergabung dalam Rumah Berdaya, Denpasar.

\section{Teknik Pengambilan Data}

Teknik pengambilan data dalam penelitian ini menggunakan tiga metode yaitu wawancara semiterstruktur, wawancara kelompok, dan observasi tak berstruktur. Wawancara semiterstruktur dilakukan dengan bantuan guideline wawancara. Pada wawancara kelompok, peneliti bertugas sebagai fasilitator agar pembicaraan tidak didominasi oleh kelompok tertentu. Observasi dilakukan bersamaan dengan proses wawancara dan fokus observasi berkembang selama kegiatan observasi berlangsung. Observasi dan wawancara dapat di catat pada catatan lapangan agar memudahkan dalam mengingat. Proses wawancara akan direkam oleh peneliti menggunakan alat perekam sehingga informasi yang diperoleh dapat disajikan dengan lengkap.

\section{Teknik Analisis Data}

Analisis data selama di lapangan dilakukan pada saat pengumpulan data berlangsung dan setelah selesai pengumpulan data dalam periode waktu tertentu. Miles dan Huberman (dalam Sugiyono, 2014), mengemukakan bahwa aktivitas dalam analisis data kualitatif dilakukan secara interaktif dan berlangsung secara terus menerus sampai tuntas dan diperoleh data jenuh. Aktivitas dalam analisis data yaitu :

Reduksi Data

Setelah peneliti melakukan pengumpulan data, maka peneliti melakukan antisipatory sebelum melakukan reduksi data. Reduksi data dapat berupa merangkum, memilih hal pokok, memfokuskan hal-hal penting, yang kemudian dicari tema serta polanya sehingga dapat memberikan gambaran yang lebih jelas dan mempermudah peneliti untuk melakukan pengumpulan data selanjutnya.

Penyajian Data (Data display)

Dalam penelitian kualitatif, penyajian data bisa dilakukan dalam bentuk uraian singkat, bagan, hubungan antar kategori, flow chart dan lainnya. Data display dapat memberikan kemudahan dalam memahami apa yang terjadi, merencanakan kerja selanjutnya berdasarkan apa yang dipahami.

Conclusion drawing atau Verification

Kesimpulan dalam penelitian kualitatif merupakan temuan baru yang sebelumnya belum pernah ada. Temuan dapat berupa deskripsi atau gambaran suatu objek yang sebelumnya masih kurang jelas sehingga menjadi jelas setelah diteliti. Untuk mendapatkan kesimpulan, sebelumnya dilakukan analisis dengan menggunakan theoretical coding yang terdiri dari open coding, axial coding serta selective coding. 


\section{Kredibilitas Penelitian}

Uji kredibilitas data atau kepercayaan terhadap data hasil penelitian kualitatif antara lain dilakukan dengan perpanjangan pengamatan, peningkatan ketekunan dalam penelitian, triangulasi, diskusi dengan teman sejawat, analisis kasus negatif dan member check (Sugiyono, 2014).

Perpanjangan Pengamatan

Perpanjangan pengamatan berarti peneliti kembali ke lapangan, melakukan pengamatan, serta melakukan wawancara kembali dengan sumber data yang pernah ditemui maupun yang baru. Dalam perpanjangan pengamatan untuk menguji kredibilitas data penelitian, sebaiknya difokuskan pada pengujian terhadap data yang telah diperoleh, apakah data yang diperoleh benar atau tidak dan berubah atau tidak. Kebenaran data yang telah diuji kembali ke lapangan menunjukkan bahwa data yang diperoleh sudah kredibel dan waktu perpanjangan pengamatan dapat diakhiri.

$\underline{\text { Peningkatan Ketekunan }}$

Meningkatkan ketekunan berarti melakukan pengamatan secara lebih cermat dan berkesinambungan. Meningkatkan ketekunan berarti peneliti melakukan pengecekan kembali apakah data yang telah ditemukan salah atau tidak, selain itu dengan meningkatkan ketekunan peneliti dapat memberikan deskripsi data yang akurat dan sistematis tentang apa yang diamati.

$\underline{\text { Triangulasi }}$

Triangulasi dalam pengujian kredibilitas diartikan sebagai pengecekan data dari berbagai sumber dengan berbagai cara dan berbagai waktu. Menguji kredibilitas dengan triangulasi sumber dilakukan dengan mengecek data yang telah diperoleh melalui beberapa sumber. Menguji kredibilitas dengan triangulasi teknik dilakukan dengan mengecek data kepada sumber yang sama dengan teknik yang berbeda, sedangkan triangulasi waktu untuk menguji kredibilitas data dilakukan dengan cara melakukan pengecekan dengan wawancara, observasi atau teknik lain dalam waktu atau situasi yang berbeda.

Analisis Kasus Negatif

Kasus negatif adalah kasus yang tidak sesuai atau berbeda dengan hasil penelitian hingga pada saat tertentu. Melakukan analisis kasus negatif berarti peneliti mencari data yang berbeda atau bahkan bertentangan dengan data yang telah ditemukan. Bila tidak ditemukan data yang berbeda atau bertentangan dengan temuan, berarti data yang diperoleh sudah dapat dipercaya.

Menggunakan Bahan Referensi

Bahan referensi yang dimaksud adalah adanya pendukung untuk membuktikan data yang telah ditemukan oleh peneliti, misalnya hasil wawancara yang didukung dengan rekaman wawancara.

Member check

Member check adalah proses pengecekan data yang diperoleh peneliti kepada pemberi data. Tujuan dari member check adalah agar informasi yang diperoleh dan akan digunakan dalam penulisan laporan sesuai dengan apa yang dimaksud sumber data atau informan.

\section{Isu Etik}

Setiap penelitian yang akan dilakukan, perlu diperhatikan isuisu etis sehingga tidak muncul rasa dirugikan pada pihak- pihak yang terlibat dalam penelitian dan dapat muncul hubungan yang baik. Agar tercipta rasa nyaman dalam proses penelitian ini, maka perlu dilakukan beberapa langkah berikut ini (Kode etik psikologi Indonesia, 2010):

Informed consent

Pasal 49 dalam Kode Etik HIMPSI terkait Informed consent dalam penelitian menyebutkan sebelum dilakukan pengambilan data, sebaiknya peneliti menjelaskan pada calon partisipan penelitian dengan menggunakan bahasa yang sederhana dan istilah-istilah yang dipahami masyarakat umum tentang penelitian yang akan dilakukan. Untuk mendapat persetujuan dari calon partisipan, penulis perlu menjelaskan proses penelitian.

Partisipan Penelitian

Pasal 48 dalam Kode Etik HIMPSI menjelaskan mengenai partisipan penelitian, yaitu melindungi perorangan atau kelompok yang akan menjadi partisipan penelitian dari konsekuensi yang tidak menyenangkan, baik dari keikutsertaan atau penarikan diri atau pengunduran dari keikut-sertaan dan berinteraksi dengan partisipan penelitian hanya di lokasi dan dalam hal-hal yang sesuai dengan rancangan penelitian, yang konsisten dengan perannya sebagai peneliti ilmiah.

\section{HASIL PENELITIAN}

Hasil pada penelitian ini berupa suatu siklus manajemen relapse pada ODS. siklus dimulai dari kondisi stabil, pencegahan tahap 1 (yang terdiri dari pencegahan yang efektif dan kurang efektif), kondisi pra-relapse, pencegahan tahap 2 (yang terdiri pencegahan yang efektif dan kurang efektif), kondisi relapse dan penanganan relapse (terdiri dari penanganan yang efektif dan kurang efektif). Siklus manajemen relapse ini akan dijelaskan ke dalam empat tema yakni, pencegahan relapse tahap pertama pada ODS, pencegahan relapse tahap kedua pada ODS, relapse pada ODS, dan penanganan relapse pada ODS.

\section{Pencegahan Relapse Tahap Pertama pada ODS}

(Bagan 1. Pencegahan Relapse Tahap Pertama pada ODS. Terlampir)

Kondisi Stabil

Kondisi stabil merupakan kondisi ketika ODS sudah mendapatkan penanganan, baik itu dengan cara minum obat, pergi ke dokter atau ke rumah sakit. Pada kondisi stabil ini biasanya ODS terlihat seperti normal (tidak memiliki gangguan) dan mampu mengerjakan beberapa aktivitas yang dapat dilakukan di rumah maupun di luar rumah.

Berdasarkan hasil dari wawancara dan observasi yang telah dilakukan maka dapat diketahui bahwa dalam keadaan stabil ODS mampu mengerjakan aktivitas sehari-hari. Beberapa aktivitas atau kegiatan yang mampu dilakukan atau dijalani oleh ODS antara lain pergi jalan-jalan, menonton televisi (TV), bekerja (part time), kuliah, melakukan pekerjaan rumah seperti membereskan rumah, menyapu dan mencuci. Pada kondisi stabil ODS juga memiliki kemauan untuk menjalani terapi dan mau mengerjakan sesuatu dengan disiplin. 
Setiap kegiatan yang mampu dilakukan oleh ODS ketika dalam kondisi stabil tetap dipengaruhi oleh kondisi ODS saat itu. Setiap aktivitas yang dilakukan merupakan atas keinginan ODS, karena aktivitas yang dipaksakan dapat memengaruhi kondisi ODS.

Pencegahan (Tahap 1)

Pencegahan yang dimaksud di sini yaitu pencegahan dari kondisi stabil menuju ke kondisi pra-relapse (gejala awal relapse). Manajemen yang dilakukan pada tahap ini akan menentukan apakah ODS dapat bertahan pada kondisi stabil atau malah menggiring ODS ke tahap pra-relapse. Pencegahan dibagi menjadi dua tipe, yaitu:

Pencegahan yang Efektif

Pencegahan yang efektif merupakan usaha yang dilakukan oleh keluarga dengan harapan akan membuat ODS bertahan lebih lama pada kondisi stabilnya. Berdasarkan hasil dari wawancara yang telah dilakukan maka dapat diketahui bahwa usaha pencegahan efektif yang dilakukan keluarga dapat berupa meminta triase (merupakan suatu tanda yang diberikan pada mahasiswa yang memiliki riwayat penyakit tertentu) pada saat orientasi studi dan pengenalan kampus (Ospek). Pencegahan lain yang dapat dilakukan yaitu dengan melakukan protect (perlindungan) dari stresor, menjaga agar ODS minum obat secara teratur dan mengajak ODS untuk rutin melakukan kontrol ke rumah sakit atau dokter serta mengajak ODS untuk beraktivitas.

Setiap pencegahan yang dilakukan keluarga merupakan hasil konsultasi atau saran dari dokter. Pencegahan juga dapat berasal dari pengalaman-pengalaman sebelumnya yang menunjukkan efektivitas terhadap kondisi ODS.

Pencegahan yang Kurang Efektif

Usaha yang dilakukan keluarga untuk membuat ODS untuk tetap stabil, namun tanpa disadari maupun disadari usaha tersebut membuat ODS menunjukkan gejala-gejala prarelapse. Salah satunya yaitu memberikan obat ketika ODS mengalami relapse saja. Keluarga menyadari pentingnya pemberian obat ketika ODS mengalami relapse, namun belum memberikan obat secara rutin yang mampu mengurangi relapse bahkan membuat ODS dapat berada pada kondisi stabil. Hal ini dapat disebabkan oleh faktor ekonomi keluarga yang kurang memadai karena harga obat antipsikotik yang terbilang mahal.

Selain dari segi keluarga, terkadang ada beberapa ODS yang kurang menyadari pentingnya minum obat secara teratur sehingga keluarga membohongi ODS agar mau diberikan obat atau disuntik obat psikotik.

Hal ini justru menyebabkan ODS tidak memiliki kesadaran akan kondisi yang dialami dan memengaruhi penerimaan atas kondisi skizofrenia yang dialami. Membohongi ODS juga akan menyulitkan keluarga ketika hendak memberikan pengobatan bagi ODS.

\section{Pencegahan Relapse Tahap Kedua pada ODS}

(Bagan 2. Pencegahan Relapse Tahap Kedua pada ODS. Terlampir)

Pra-relapse
Pra-relapse digambarkan sebagai gejala awal munculnya relapse. Keluarga yang biasa mengurus ODS biasanya akan peka atau menyadari apabila terdapat tingkah laku yang berbeda pada ODS yang menunjukkan gejala awal munculnya relapse.

Berdasarkan hasil dari wawancara dan observasi yang dilakukan dapat diketahui bahwa gejala pra-relapse yang biasa muncul secara perilaku pada ODS yaitu gangguan tidur (tidak bisa tidur atau merasa selalu mengantuk). Keluarga akan melihat perbedaan yang terjadi ketika ODS mulai tidak bisa tidur atau bahkan ODS merasa selalu mengantuk dan langsung melakukan pencegahan agar gejala relapse tidak muncul. Gejala pra-relapse juga ditunjukkan ketika ODS mengalami pusing dan perkataannya mulai tidak jelas.

Pada kondisi ini keluarga harus memahami gejala-gejala khusus yang dialami ODS karena setiap ODS akan memunculkan gejala yang berbeda. Gejala yang diketahui lebih awal akan membantu keluarga memberikan tindakan yang tepat bagi ODS.

Pencegahan (Tahap 2)

Pada tahap ini, apabila keluarga merasakan munculnya gejalagejala awal terjadinya relapse (pra-relapse) maka keluarga dapat melakukan pencegahan agar tidak terjadi relapse. Pencegahan pada tahap ini juga dibagi menjadi 2 tipe, yaitu: Pencegahan yang Efektif

Sama seperti pencegahan pada fase diantara fase stabil dengan fase pra-relapse, pencegahan ini merupakan usaha keluarga agar ODS hanya mencapai fase pra- relapse dan mencegah terjadinya relapse.

Berdasarkan hasil dari wawancara dan observasi yang telah dilakukan dapat diketahui bahwa salah satu cara pencegahan yang dilakukan keluarga agar tidak terjadi relapse pada ODS yaitu dengan cara langsung memberi obat ketika gejala-gejala pra-relapse muncul. Selain itu bisa juga melakukan konsultasi dengan dokter untuk mengetahui apa yang semestinya dilakukan oleh keluarga sehingga penanganan yang diberikan dapat memberikan hasil yang baik atau efektif membuat kondisi ODS kembali stabil.

\section{Pencegahan yang Kurang Efektif}

Usaha yang dilakukan keluarga untuk membuat ODS tidak mencapai fase relapse, namun tanpa disadari maupun disadari usaha tersebut membuat ODS menunjukkan gejala-gejala relapse. Pencegahan pada fase ini memiliki kesamaan dengan pencegahan yang sebelumnya, yaitu keluarga hanya memberikan obat hanya ketika gejala relapse sudah muncul dan membohongi ODS agar mau melakukan konsumsi obat. Pada beberapa ODS, setelah dibohongi untuk konsumsi obat dan merasa bahwa dirinya lebih baik setelah mengonsumsi obat maka ODS akan meminta sendiri obat yang diperlukan.

Walau membohongi ODS juga dapat memberikan kesadaran akan pentingnya konsumsi obat bagi ODS, namun beberapa orangtua ODS menyarankan untuk tetap memberikan pengertian terkait dengan kondisi ODS sehingga untuk selanjutnya keluarga dapat lebih mudah melakukan pengobatan bagi ODS. Setiap ODS memiliki respon yang 
berbeda, sehingga membohongi ODS ketika akan memberikan obat tidak dianjurkan.

\section{Relapse pada Orang dengan Skizofrenia}

(Bagan 3. Relapse pada Orang dengan Skizofrenia. Terlampir)

Relapse

Pada fase ini, ODS mengalami kembali simtom-simtom atau gejala-gejala skizofrenia. Apabila ODS mencapai pada tahap ini berarti pencegahan yang dilakukan kurang maksimal atau kurang efektif. Pada bagian ini akan dijelaskan beberapa penjabaran hasil yang diperoleh, terkait:

Bentuk Relapse

Terdapat beberapa bentuk relapse yang dibedakan menjadi:

\section{Bentuk Relapse Secara Kognitif}

Relapse pada bentuk ini dapat berwujud pikiran-pikiran negatif yang dirasakan oleh ODS walaupun pada kenyataannya apa yang dipikirkan tersebut tidak pernah terjadi. Pikiran-pikiran ini yang menyebabkan kondisi ODS menurun, menimbulkan kecemasan dan menimbulkan gejala relapse.

Berdasarkan hasil dari wawancara dan observasi yang telah dilakukan maka dapat diketahui bahwa salah satu bentuk relapse secara kognitif yaitu curiga yang tidak beralasan dan berlebihan yang dipikirkan oleh ODS. Kecurigaan ini membuat keluarga sulit melakukan aktivitas terutama yang berhubungan dengan interaksi dengan lingkungan sekitar, misalnya suami yang memiliki istri seorang ODS sulit melakukan interaksi dengan tetangga maupun saudara yang berlawanan jenis karena istrinya sering curiga dengan suaminya.

Curiga yang berlebihan juga memengaruhi pekerjaan dari responden karena ketika akan berangkat bekerja responden harus meminta izin terlebih dahulu pada istrinya. Hal ini juga membatasi gerak responden karena takut menimbulkan pikiran curiga pada istrinya.

\section{Bentuk Relapse Secara Perilaku}

Relapse pada bentuk ini dapat berwujud perilaku-perilaku yang tidak sesuai dengan kebiasaan-kebiasaan ODS ketika dalam kondisi stabil atau sebelum mengalami skizofrenia, atau dapat dikatakan bahwa perilaku-perilaku yang muncul ketika ODS mengalami relapse berlawanan dengan perilaku yang muncul ketika ODS dalam kondisi stabil.

Berdasarkan hasil dari wawancara dan observasi yang telah dilakukan diperoleh bahwa bentuk relapse secara perilaku antara lain yaitu ketika ODS berada dalam fase relapse maka ODS akan menjadi agresif, lebih banyak berbicara, sulit untuk minum obat dan berobat ke dokter, ODS menjadi diam saja (hanya duduk dengan posisi yang sama dalam waktu yang cukup lama pada satu tempat yang sama), namun ada pula ODS yang mengamuk ketika relapse, mengalami gangguan makan (makan berlebih atau tidak mau makan), sulit tidur, mengonsumsi obat secara berlebihan dan memukul menggunakan barang-barang yang ada di sekitarnya.
Perilaku yang muncul dapat berbeda-beda pada ODS, biasanya perilaku yang muncul berlawanan dengan kebiasaan yang dilakukan ODS ketika dalam kondisi stabil. Apabila pada kondisi stabil ODS merupakan individu yang pendiam maka pada kondisi relapse ODS mampu menjadi individu yang agresif atau banyak bicara.

\section{Bentuk Relapse Secara Emosi}

Relapse pada bentuk ini dapat berupa emosi-emosi yang tidak sesuai dengan kebiasaan ketika ODS berada dalam keadaan stabil, emosi yang muncul tanpa sebab atau emosi yang biasanya tidak muncul pada orang normal lainnya. Berdasarkan hasil dari wawancara dan observasi yang dilakukan dapat diketahui bahwa bentuk relapse secara emosi antara lain yaitu tertawa sendiri tanpa sebab, tiba-tiba menangis dan marah dalam jangka waktu yang singkat.

Penyebab Relapse

Selain mengetahui bentuk-bentuk relapse pada ODS, keluarga juga perlu memerhatikan penyebab-penyebab yang memungkinkan munculnya relapse. Terdapat 3 penyebab utama yang dapat menimbulkan relapse pada ODS, yaitu:

\section{Konsumsi obat atau pengobatan}

Obat atau pengobatan merupakan salah satu hal yang patut diperhitungkan sebagai penyebab relapse. Berdasarkan hasil dari wawancara dan observasi yang telah dilakukan dapat diketahui bahwa penyebab relapse salah satunya berada pada aspek konsumsi obat atau pengobatan, seperti ODS yang malas minum obat, dosis obat yang sempat dikurangi, dan tidak rutin berobat atau ketidakdisiplinan dalam berobat.

Konsumsi obat yang harus dilakukan setiap hari tidak jarang menyebabkan ODS mengalami rasa jenuh. Hal ini yang menyebabkan ODS malas untuk mengonsumsi obat dan berujung pada munculnya gejala relapse. Kondisi ini dapat ditangani dengan memberikan dukungan dan penjelasan oleh keluarga pada ODS sehingga ODS memiliki semangat untuk mengonsumsi obat secara teratur.

\section{Kognitif atau Pikiran}

Pada bentuk-bentuk relapse telah disebutkan bahwa salah satu bentuk relapse secara kognitif yaitu curiga. Selain menjadi bentuk dari relapse, pikiran curiga ini juga menjadi salah satu penyebab munculnya relapse. Berdasarkan hasil dari wawancara dan observasi yang telah dilakukan dapat diketahui bahwa penyebab relapse salah satunya berada pada aspek kognitif dari ODS, seperti pikiran curiga terhadap seseorang, terutama ketika pasangan dari ODS berinteraksi dengan seseorang yang berlawanan jenis dan bukan merupakan anggota keluarga dapat menyebabkan curiga yang berlebihan dan mendorong munculnya relapse.

\section{Event atau situasi}

Selain konsumsi obat dan emosi yang dirasakan ODS, kejadian atau situasi yang dialami ODS juga mampu menjadi penyebab munculnya relapse. Salah satu kejadian atau situasi yang dapat menyebabkan munculnya relapse yaitu ketika ODS dipaksakan melakukan hal yang tidak disukai atau disenangi. Hal yang tidak disenangi ini menyebabkan ODS menjadi stres dan mendorong timbulnya relapse. Selain itu, 
hal-hal yang membuat ODS bingung juga dapat memicu timbulnya relapse pada ODS.

Hal ini menunjukkan bahwa keluarga diharapkan tidak memaksakan sesuatu pada ODS. Setiap aktivitas dapat dilakukan secara bertahap agar ODS tidak merasa lelah. Kelelahan pada ODS dapat menurunkan kondisi dan menimbulkan gejala relapse.

Periode atau Waktu Relapse

Keluarga ODS terkadang sulit dalam menentukan kapan relapse akan muncul. Berdasarkan hasil dari wawancara dan observasi yang dilakukan dapat diketahui bahwa periode atau waktu relapse yang dialami oleh ODS tidak menentu apabila dilihat secara interval. Tidak menentunya kemunculan relapse dapat membuat keluarga merasa khawatir, sehingga keluarga melakukan pencegahan agar relapse tidak muncul atau setidaknya mengurangi frekuensi kemunculan relapse. Hal ini juga diharapkan membuat keluarga selalu melakukan persiapan apabila sewaktu-waktu gejala relapse muncul.

Kesiapan Keluarga Menghadapi Relapse

Selain melakukan penanganan maupun pencegahan, keluarga juga patut melakukan hal-hal tertentu untuk mengantisipasi apabila sewaktu-waktu ODS mengalami relapse. Seperti yang dijelaskan sebelumnya bahwa kemunculan relapse terkadang tidak dapat diprediksi dan perilaku yang muncul pada saat relapse mungkin saja berbeda-beda, sehingga penting bagi keluarga untuk melakukan pengaturan-pengaturan seperti penempatan senjata tajam yang dapat melukai ODS maupun keluarga ODS. Alat-alat rumah tangga seperti kompor dan gas juga perlu diperhatikan, terutama saat ODS ditinggal sendiri dirumah.

Berdasarkan hasil dari wawancara dan observasi yang dilakukan dapat diketahui bahwa salah satu cara keluarga untuk memperlihatkan kesiapannya untuk menghadapi ODS yang mengalami relapse adalah melepas gas pada kompor ketika pergi sehingga keselamatan ODS terjaga. Cara lain yang dilakukan keluarga untuk menghadapi keadaan relapse pada ODS yaitu menyimpan senjata tajam dengan baik.

\section{Penanganan Relapse pada ODS}

(Bagan 4. Penanganan Relapse pada ODS. Terlampir) Penanganan

Penanganan yang dilakukan merupakan usaha untuk mengurangi perilaku relapse bahkan menghilangkan perilaku yang muncul ketika relapse sehingga ODS dapat kembali ke keadaan stabil. Penanganan yang diberikan dibagi menjadi 2 tipe, yaitu:

Penanganan yang Efektif

Penanganan yang efektif merupakan usaha keluarga untuk membuat ODS yang berada dalam keadaan relapse menjadi kembali normal. Berdasarkan hasil dari wawancara dan observasi dapat diketahui bahwa bentuk penanganan yang efektif untuk membuat ODS kembali stabil dari fase relapse yaitu dengan membawa ODS ke rumah sakit, memberikan obat atau bertanggung jawab atas konsumsi obat yang dilakukan ODS, dan memberikan perhatian keluarga.

Perhatian keluarga juga dapat diartikan sebagai dukungan keluarga pada ODS. Dukungan keluarga dapat berupa kesediaan keluarga untuk mengantar ODS ke rumah sakit, melakukan kontrol terhadap konsumsi obat dan merawat ODS. Penanganan yang Kurang Efektif

Berbanding terbalik dengan bentuk-bentuk penanganan yang efektif, penanganan yang kurang efektif memang mampu mengembalikan ODS ke fase stabil, namun penanganan yang diberikan tidak menunjukkan peningkatan dalam jangka panjang. Berdasarkan hasil dari wawancara dan observasi dapat diketahui bahwa beberapa penanganan yang kurang efektif diantaranya memukul ODS, hanya membiarkan ODS tidur, kurang melakukan kontrol terhadap lingkungan rumah sakit, mengajak ke pengobatan non-profesional dan memberikan obat hanya ketika ODS mengalami relapse. Keluarga yang melakukan kekerasan seperti memukul ODS mengaku bahwa setelah memukul ODS timbul rasa bersalah. Ini dipengaruhi oleh pengetahuan keluarga terhadap penanganan bagi ODS yang masih kurang.

Pengobatan non-profesional lebih banyak dipengaruhi oleh budaya maupun kepercayaan masyarakat yang menganggap bahwa skizofrenia merupakan kutukan dari leluhur maupun guna-guna yang dikirim oleh orang-orang tertentu, sehingga pengobatan yang dilakukan ke dukun atau balian.

Sumber Informasi terkait Penanganan

Terdapat beberapa sumber informasi terkait hal-hal yang harus dilakukan untuk menangani keadaan relapse pada ODS yaitu pertama adalah dokter, kedua yaitu sesama keluarga dari ODS dan ketiga yaitu tenaga kesehatan lainnya (seperti psikolog atau perawat).

Berdasarkan hasil tersebut, diketahui bahwa peran dokter, perawat maupun tenaga medis lainnya sangat membantu keluarga dalam meningkatkan wawasan terkait penanganan relapse pada ODS. Tidak hanya tenaga medis, keluarga lain juga dapat menjadi sumber informasi berdasarkan pengalaman-pengalaman yang telah dialami.

\section{PEMBAHASAN}

Berdasarkan hasil penelitian yang telah dipaparkan maka pembahasan akan dilakukan terkait dengan siklus manajemen relapse yang ditemukan yaitu dimulai dengan fase atau kondisi stabil, pencegahan agar tidak muncul pra-relapse (pencegahan tahap 1), fase atau kondisi pra-relapse, pencegahan agar tidak relapse (pencegahan tahap 2), fase atau kondisi relapse (terkait bentuk-bentuk relapse, penyebab relapse, periode atau waktu relapse dan kesiapan keluarga menghadapi relapse), serta penanganan ketika ODS mengalami relapse.

\section{Fase atau Kondisi Stabil}

Hasil penelitian yang dilakukan menemukan bahwa, pada kondisi stabil ODS dapat melakukan aktivitas sehari-hari baik di rumah maupun di luar rumah, seperti pergi jalan-jalan, menonton TV, bekerja, kuliah serta melakukan pekerjaan rumah seperti membereskan rumah, menyapu dan mencuci. Hasil ini sesuai dengan penelitian yang dilakukan oleh Putri dan Ambarini (2012) terkait makna hidup pada ODS pasca rawat inap yang menemukan hasil bahwa pada subjek 1, pasca melakukan rawat inap, subjek 1 berusaha memaknai hidupnya 
dengan melalui nilai kreatifnya dengan terus berusaha agar selalu menjadi lebih baik dari kondisinya saat ini karena adanya tanggung jawab yang dirasakan melalui perannya sebagai suami, sehingga subjek terus berusaha membuat dirinya lebih bermakna dengan bekerja apapun yang bisa membantu pendapatan keluarganya. Salah satu cara yang dilakukan oleh subjek 1 yaitu berjualan di pasar.

Pada subjek 2, hidup dimaknai dengan biasa saja dan merasa nyaman dengan kondisi yang sedang dijalani sehingga kurang menjalani proses lebih untuk mencapai makna hidup. Subjek 2 merasa bahagia ketika bersenang-senang dengan temannya. Dapat diperoleh kesimpulan bahwa terjadinya perbedaan dalam berperilaku dan memaknai hidup dipengaruhi oleh peran dan tanggung jawab yang harus dipenuhi dan tipe skizofrenia yang diderita subjek (Putri \& Ambarini, 2012).

Penelitian yang dilakukan oleh Michele, Bolino, Mazza, Roncone, \& Casacchia (2007) menyebutkan bahwa ODS yang tidak dalam keadaan relapse (keadaan stabil) memiliki karakteristik seperti, dapat berfungsi secara baik, simtom positif yang lebih rendah, memiliki kemampuan yang lebih tinggi dalam merawat diri. Evaluasi klinis awal pada ODS yang berada pada kondisi stabil juga menunjukan bahwa ODS memiliki IQ yang lebih tinggi (Michele, Bolino, Mazza, Roncone, \& Casacchia, 2007).

\section{Pencegahan Tahap 1}

Pencegahan tahap 1 ini merupakan pencegahan yang dilakukan agar ODS tetap berada pada fase atau kondisi stabil dan mencegah munculnya gejala-gejala pra- relapse. Hal-hal yang dilakukan keluarga untuk mencegah terjadinya prarelapse ini antara lain meminta triase pada saat ospek, melakukan protect dari stresor, mengingatkan ODS untuk teratur minum obat, rutin melakukan kontrol ke rumah sakit atau dokter dan mengajak ODS beraktivitas. Pencegahanpencegahan tersebut termasuk ke dalam pencegahan yang efektif.

Hal ini sejalan dengan cara-cara pencegahan yang dijelaskan oleh KPSI dan Fakultas Ilmu Keperawatan UI yang menyebutkan cara pencegahan yang dapat dilakukan yaitu (1) dari segi ODS yaitu minum obat secara teratur, kemudian (2) dari keluarga dapat menciptakan lingkungan yang bersahabat, memberikan pujian pada ODS ketika melakukan sesuatu dengan baik, melibatkan ODS dalam kegiatan kebersamaan dengan anggota keluarga yang lain, keluarga mendukung pengobatan ODS misal dengan melakukan pengawasan minum obat dan membawa berobat secara rutin ke Puskesmas atau rumah sakit serta (3) dari lingkungan masyarakat dapat memberikan lingkungan yang nyaman dan aman seperti tidak mengejek (Pencegahan kekambuhan pada orang dengan gangguan kejiwaan, 2015). Selain itu, cara yang dapat dilakukan untuk mencegah terjadinya pra-relapse atau relapse yaitu dengan menerapkan 5B (Berobat, Bicara, Bekerja, Berolahraga dan Berdoa) (Lestari M. R., 2017). Hal ini sejalan dengan apa yang telah dilakukan oleh responden dalam melakukan pencegahan tahap I.

\section{Fase atau Kondisi Pra-relapse}

Berdasarkan hasil yang diperoleh, fase atau kondisi prarelapse ditandai dengan gejala-gejala secara perilaku seperti ODS yang mengalami gangguan tidur (sulit tidur atau merasa selalu mengantuk), pusing dan berbicara tidak jelas. Berdasarkan hasil penelitian yang dilakukan oleh Birchwood, Spencer, \& McGovern (2000) menyebutkan bahwa tandatanda awal kekambuhan yaitu 'dysphoric' symptoms seperti merasa tertekan, menarik diri, masalah terkait tidur dan nafsu makan (Birchwood, Spencer, \& McGovern, 2000). Taylor, et al., 2005 menjelaskan bahwa tanda awal relapse antara lain: perubahan psikososial, menurunnya kemampuan kognitif, serta ODS mengalami kesulitan tidur.

\section{Pencegahan Tahap 2}

Pencegahan pada tahap 2 ini dilakukan agar fase atau kondisi pra-relapse yang dialami ODS berlanjut ke fase atau kondisi relapse. Bentuk pencegahan yang dilakukan pada tahap ini hampir sama dengan pencegahan tahap 1 yaitu memberikan ODS obat agar gejala tidak berlanjut ke fase atau kondisi relapse. Salah satu penanganan yang dapat dilakukan ketika muncul gejala pra-relapse adalah dengan obat atau mengajak ODS untuk melakukan konsultasi ke dokter. Pengobatan dimulai pada pengembangan tanda peringatan dini yang dikombinasi dengan perawatan obat telah menunjukkan penurunan tingkat kekambuhan psikotik mencapai 12 hingga 23 persen selama dua tahun (Marder et al, 1984, 1987; Jolley et al, 1990; Gaebel et al, 1993 dalam Birchwood, Spencer, \& McGovern, 2000).

\section{Fase atau Kondisi Relapse}

Beberapa bentuk relapse secara perilaku dapat berupa perilaku yang lebih agresif, lebih banyak berbicara, mengamuk dan memukul. Hal ini sejalan dengan penelitian yang dilakukan oleh Taylor, et al., (2005) yang menjelaskan bahwa gejala relapse ditunjukkan dengan meningkatnya simtom positif.

Fase atau kondisi relapse disebabkan oleh beberapa faktor, di antaranya: ODS yang malas minum obat, dosis obat yang dikurangi, tidak rutin berobat, curiga, mengerjakan hal yang tidak disenangi dan terdapat hal-hal yang menimbulkan kebingungan pada ODS. Hal ini sejalan dengan sebuah penelitian yang menyebutkan bahwa penyebab relapse antara lain faktor ekonomi, ketidakpatuhan ODS pada pengobatan, mendapat perlakuan kasar dan pertengkaran yang terus menerus dengan saudara kandung, konflik yang berkepanjangan dengan istri, dan emosi (marah) yang diekspresikan secara berlebihan oleh keluarga (Amelia \& Anwar, 2013). Menurut KPSI dan Ilmu Keperawatan UI (2015) menyebutkan bahwa penyebab munculnya relapse yaitu ODS berhenti minum obat, tidak bekerja, konflik dengan keluarga, keinginan yang tidak terpenuhi serta pengalaman yang tidak menyenangkan (Pencegahan kekambuhan pada orang dengan gangguan kejiwaan, 2015).

\section{Penanganan Relapse}

Penanganan relapse dibagi menjadi 2, yaitu penanganan yang baik dan penanganan kurang baik. Penanganan yang baik antara lain di bawa ke rumah sakit, memberikan obat, dan perhatian keluarga. Bentuk dukungan keluarga terhadap 
penderita tidak hanya terbatas pada perilaku minum obat, namun juga dalam keseharian ODS. Dukungan keluarga yang diberikan terdiri dari: dukungan instrumental, dukungan informatif, dan dukungan emosional. Adapun contoh dukungan keluarga yang diberikan seperti menyiapkan obat setiap hari, memberi pengertian dan nasehat pada penderita agar mau minum obat, serta memiliki perasaan kasihan terhadap ODS (Minarni \& Sudagijono, 2015).

Penanganan relapse juga dapat dilakukan dengan melakukan manajemen skizofrenia, salah satunya dengan menerapkan terapi berbasis keluarga. Terapi berbasis keluarga merupakan terapi yang efektif. Manajemen skizofrenia juga bertujuan untuk meningkatkan kualitas hidup ODS, meningkatkan kemandirian ODS, dan juga menurunkan tingkat relapse pada ODS (Taylor, et al., 2005).

\section{KESIMPULAN DAN SARAN}

\section{Kesimpulan}

Relapse yaitu keadaan munculnya gejala yang sama seperti sebelumnya dan mengakibatkan harus dirawat kembali. Kekambuhan pada ODS yaitu munculnya kembali gejalagejala psikotik yang nyata. Manajemen yang dapat dilakukan keluarga terhadap relapse pada ODS yaitu merupakan suatu siklus yang dimulai pada kondisi stabil ODS yang dilanjutkan dengan pencegahan agar tidak terjadi pra-relapse. Apabila pencegahan yang dilakukan kurang maksimal, maka akan memungkinkan terjadinya pra-relapse seperti tidak bisa tidur.

Saat muncul gejala pra-relapse, keluarga dapat pula melakukan pencegahan agar pra-relapse tidak berlanjut menjadi relapse. Pencegahan yang dilakukan berupa memberikan obat pada ODS. Apabila pencegahan yang dilakukan kurang efektif, maka ODS dapat masuk pada tahap relapse. Relapse dibedakan menjadi 3 bentuk, yaitu bentuk relapse secara kognitif (curiga), bentuk relapse secara perilaku (agresif, banyak bicara, tidak mau minum obat, tidak mau berobat ke dokter, diam saja, mengamuk, gangguan makan, sulit tidur, minum obat berlebihan dan memukul), dan bentuk yang ketiga yaitu bentuk relapse secara emosi atau afektif (tertawa, menangis dan marah).

Penanganan yang dapat diberikan ketika ODS mengalami relapse dibagi menjadi 2 yaitu penanganan yang baik seperti membawa ODS ke rumah sakit, memberikan obat dan memberikan perhatian keluarga. Selain penanganan yang baik, keluarga juga dapat memberikan penanganan yang kurang baik seperti memukul ODS ketika relapse, hanya membiarkan ODS tidur, kurang melakukan kontrol terhadap lingkungan rumah sakit, mengajak ke pengobatan non-profesional dan hanya memberikan obat ketika ODS relapse saja.

\section{Saran}

Terdapat sejumlah saran yang dapat direkomendasikan bagi keluarga ODS, ODS, masyarakat, petugas kesehatan, dan peneliti selanjutnya. Saran untuk keluarga ODS antara lain, keluarga sebaiknya mampu mengenali setiap gejala-gejala yang muncul pada ODS sehingga keluarga dapat memberikan penanganan yang tepat, keluarga diharapkan dapat mengontrol konsumsi obat pada ODS sehingga ODS mengonsumsi obat secara teratur dan dapat mengurangi bahkan mencegah munculnya relapse, keluarga mengetahui langkah- langkah yang dilakukan ketika ODS mengalami relapse sehingga ODS mampu kembali ke kondisi stabil, keluarga mengajak ODS untuk melakukan hal yang positif dan memberikan kepercayaan pada ODS untuk melakukan sesuatu sehingga mampu meningkatkan kemandirian serta interaksi sosial ODS.

Saran bagi ODS sendiri yaitu ODS sebaiknya mengonsumsi obat secara teratur sehingga dapat bertahan pada kondisi stabil, ODS mau terbuka dan memberitahukan pada keluarga terkait keluhan-keluhan yang dialami, dan ODS dapat melakukan aktivitas- aktivitas yang positif sehingga dapat lebih produkif. Saran bagi masyarakat antara lain, masyarakat mampu membantu keluarga dari ODS untuk membentuk lingkungan yang nyaman baik bagi keluarga maupun ODS sehingga ODS merasa bahwa dirinya diterima dimasyarakat dan mampu untuk beraktivitas seperti mayarakat pada umumnya, masyarakat mampu membantu keluarga dari ODS untuk melakukan pengawasan apabila keluarga tidak di rumah sehingga keluarga merasa bahwa keluarga dari ODS tidak dikucilkan, namun tetap mendapatkan dukungan untuk merawat ODS. Masyarakat dapat membantu ODS untuk beradaptasi dengan lingkungan dan menjadi lebih produktif sehingga ODS dapat menjalani kehidupan normal seperti masyarakat pada umumnya. Kesempatan untuk ikut berkontribusi dalam kegiatan yang terdapat dimasyarakat dapat menjadi salah satu cara untuk melatih interaksi sosial ODS.

Saran bagi petugas kesehatan antara lain, diharapkan petugas kesehatan (dokter, perawat, psikiater maupun psikolog) mampu memberikan informasi terkait pencegahan dan penanganan relapse pada ODS sehingga keluarga mampu memberikan penanganan yang tepat ketika ODS mengalami relapse. Informasi dapat berupa poster atau pesan bergambar yang berisi langkah-langkah dalam melakukan pencegahan maupun penanganan relapse, serta diharapkan petugas kesehatan dapat memberikan dukungan pada keluarga sehingga keluarga dapat terus melakukan kontrol pada ODS, dan pengobatan dapat berlangsung secara terus-menerus. Suasana yang nyaman akan memberikan semangat pada keluarga untuk terus mengajak ODS melakukan perawatan atau pengobatan. Saran bagi peneliti selanjutnya yaitu peneliti selanjutnya diharapkan dapat melakukan pengambilan data (wawancara dan observasi) lebih mendalam sehingga hasil yang diperoleh akan lebih bervariasi serta diharapkan dapat mencari sumber-sumber atau referensi yang lebih bervariasi terkait relapse sehingga memperkaya informasi terkait relapse itu sendiri.

\section{DAFTAR PUSTAKA}

Kode etik psikologi Indonesia. (2010). Surakarta: Pengurus Pusat Himpunan Psikologi Indonesia.

(2015). Pencegahan kekambuhan pada orang dengan gangguan kejiwaan. Jakarta: KPSI \& Fakultas Ilmu Keperawatan Universitas Indonesia .

Amelia, D. R., \& Anwar, Z. (2013, Januari). Relaps pada pasien skizofrenia. Jurnal Ilmiah Psikologi Terapan, 01, 53-65. 
Birchwood, M., Spencer, E., \& McGovern, D. (2000). Schizophrenia: Early warning signs.

Advances in Psychiatric Treatment, 6, 93-101.

Davison, G. C., Neale, J. M., \& Kring, A. M. (2014). Psikologi abnormal (9 ed.). (N. Fajar, Trans.) Jakarta: Rajawali Pers.

Idaiani, S., Yunita, I., Prihatini, S., \& Indrawati, L. (2013). Riset kesehatan dasar 2013.

Jakarta: Kementerian Kesehatan RI.

Indonesia, R. (1992). Undang-undang no. 23 tahun 1992 tentang kesehatan. Jakarta: Sekretariat Negara.

Lestari, M. R. (2017, Januari 08). Kenali 5B, cara sederhana obati skizofrenia. (L. Eppang, Editor) Retrieved Juni 19, 2017, from netralnews.com: www.netralnews.com/news/nasional/read/46733/kenali.5b. cara.sederhana.obati.ski zofrenia.

Lestari, W., \& Wardhani, Y. F. (2014, April). Stigma dan penanganan penderita gangguan jiwa berat yang dipasung. Buletin Penelitian Sistem Kesehatan, 17, 157-166.

Maslim, R. (2013). Diagnosis gangguan jiwa, rujukan ringkas PPDGJ-III dan DSM-5.

Jakarta: PT Nuh Jaya.

Michele, V. D., Bolino, F., Mazza, M., Roncone, R., \& Casacchia, M. (2007, March). Relapsing versus non relapsing course of schizophrenia: A cohort study in a community based mental health service. Epidemiology and Psychiatric Sciences, 16, $50-58$.

Minarni, L., \& Sudagijono, J. S. (2015, Oktober). Dukungan keluarga terhadap perilaku minum obat pada pasien skizofrenia yang sedang rawat jalan. Jurnal Experientia, 3 (2), 13-22.

Moleong, L. J. (2014). Metodologi penelitian kualitatif. Bandung: PT Remaja Rosdakarya.

Mundakir. (2015, Maret). Faktor yang mempengaruhi pemasungan pada pasien gangguan jiwa. The Sun, 2, 4-11.

Putri, P. K., \& Ambarini, T. K. (2012, Desember). Makna hidup penderita skizofrenia pasca rawat inap. Jurnal Psikologi Klinis dan Kesehatan Mental, 01 No 03, 118- 123.

Rao, S. (2013). Management of relapse in schizophrenia. The Singapore Family Physician, 39 (1), 22-25.

Sugiyono. (2014). Metode penelitian kombinasi (mixed methods). Bandung: Alfabeta.

Taufik, Y. (2014). Hubungan dukungan keluarga dengan tingkat kekambuhan pada pasien skizofrenia di Poliklinik Rumah Sakit Jiwa Grhasia DIY.

Taylor, M., Chaudhry, I., Cross, M., McDonald, E., Miller, P., Pilowsky, L., et al. (2005). Towards consensus in the longterm management of relapse prevention in schizophrenia. Human Psychopharmacology, 20, 175-181. 


\section{LAMPIRAN}

Bagan 1

Pencegahan Relapse Tahap Pertama pada ODS

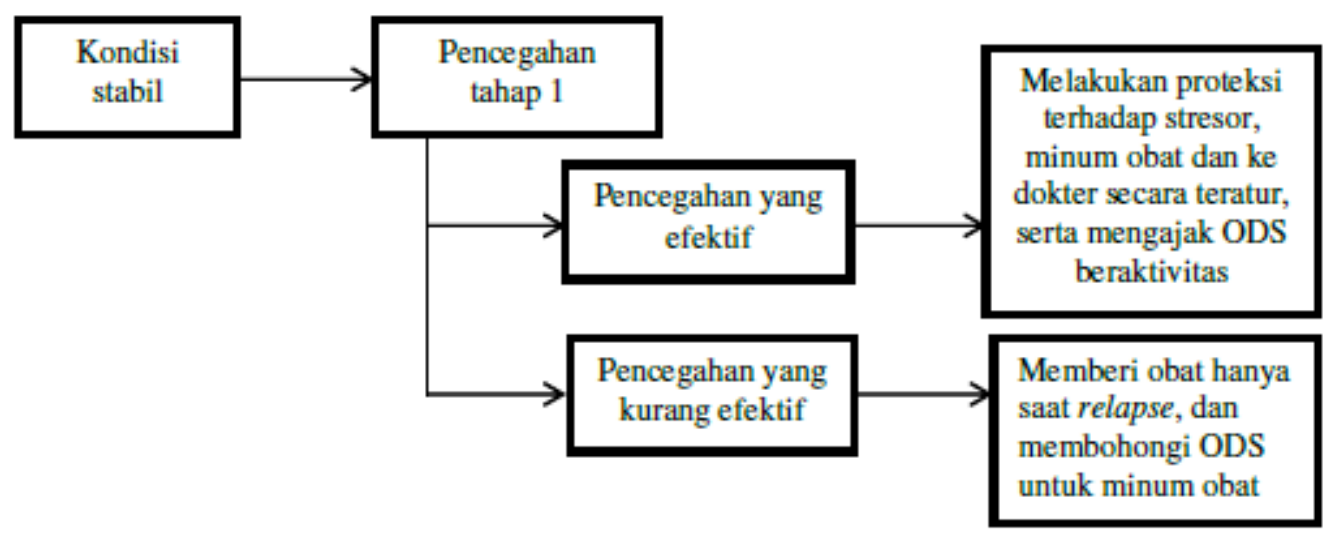




\section{Bagan 2}

Pencegahan Relapse Tahap Kedua pada ODS

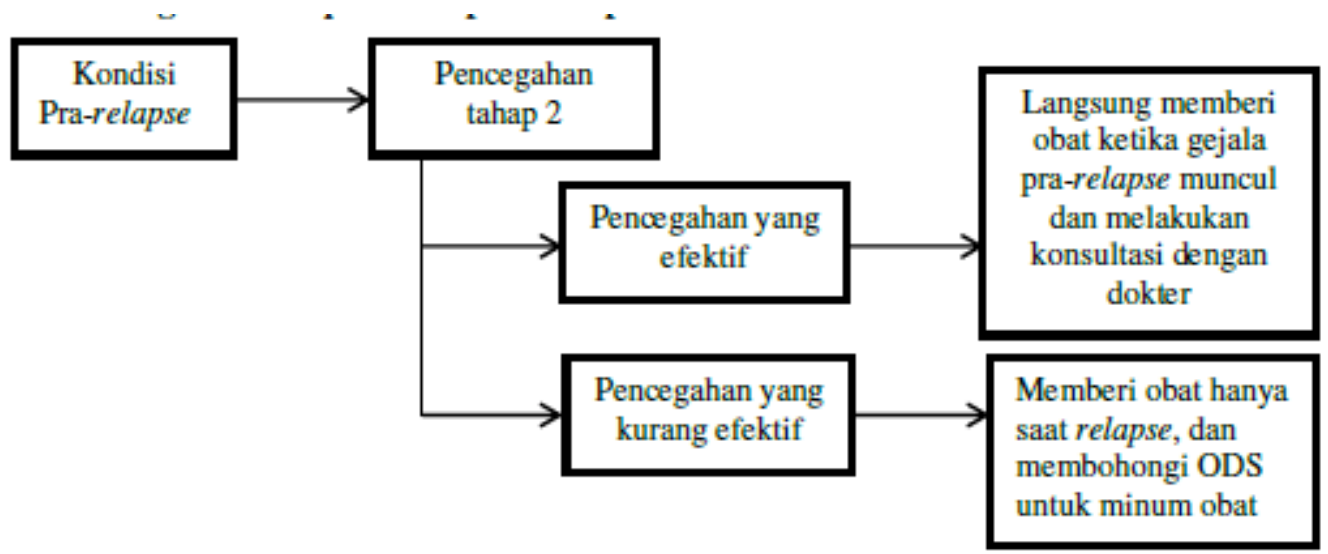


Bagan 3

Relapse pada Orang dengan Skizofrenia

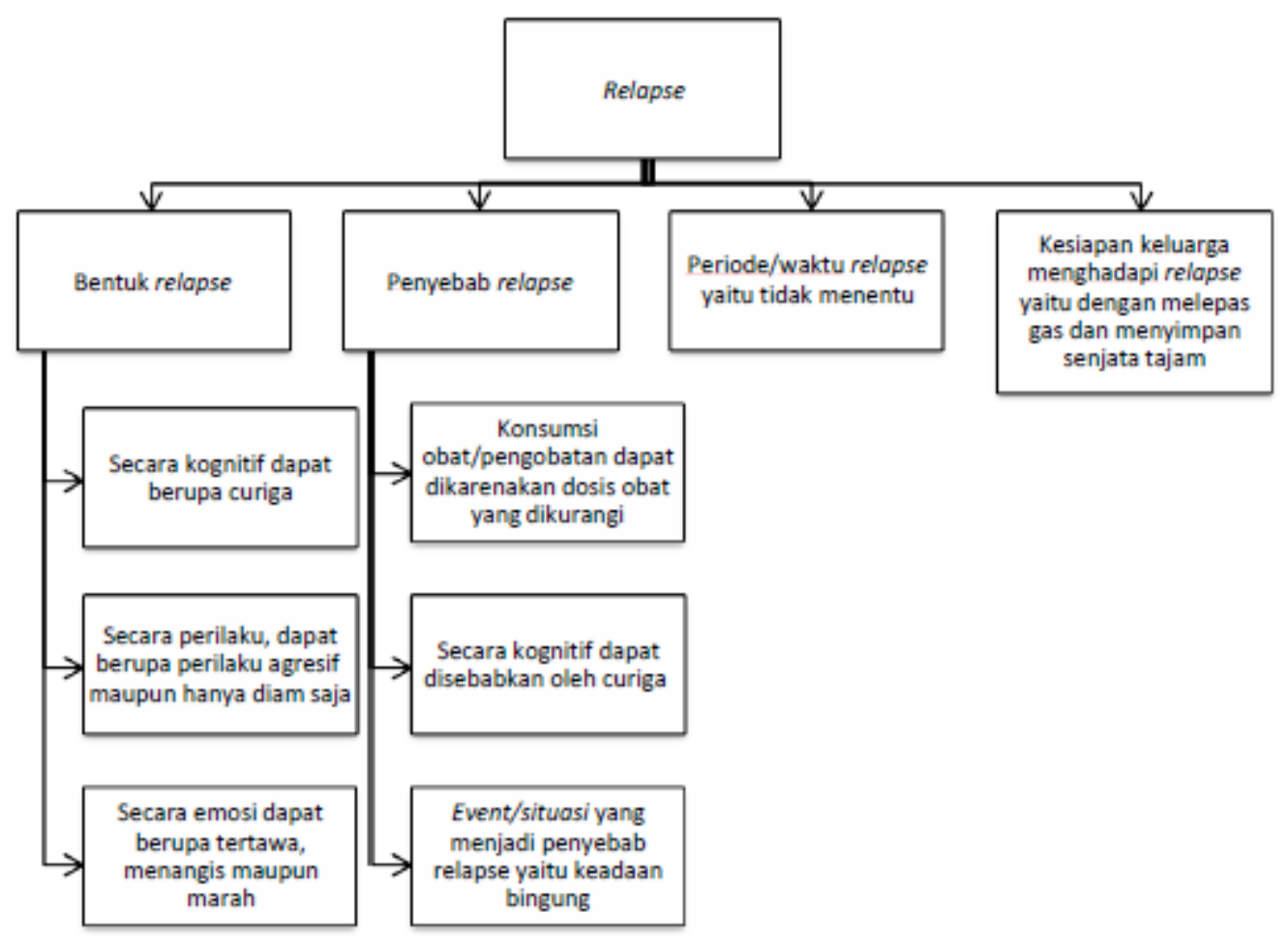




\section{Bagan 4.}

Penanganan Relapse pada ODS

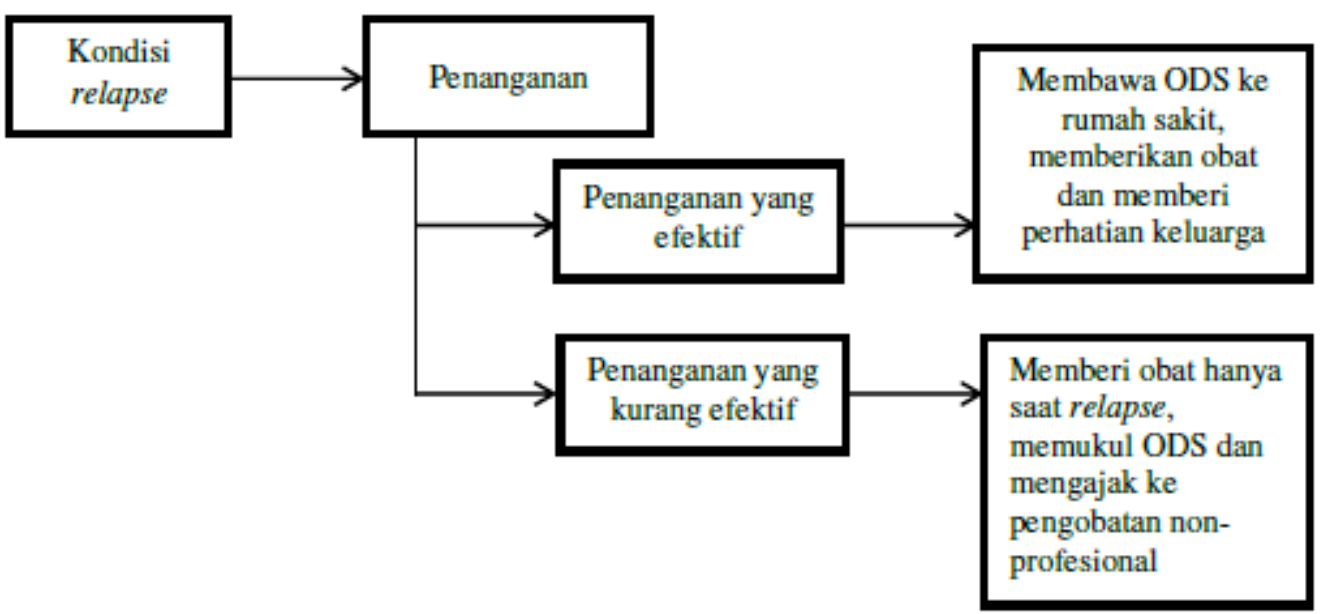

